\title{
LEPROSY AND RHEUMATOLOGICAL MANIFESTATIONS, OBSERVED IN THE COUNTRYSITE OF PERNAMBUCO
}

Helcias Nascimento Leonardo de Lima ${ }^{1}$, Luiz Eduardo de Azevedo Ramos da Silva ${ }^{1, \star}$, Elisa Teresinha Hacbarth Freire ${ }^{1}$, Ana Paula Bazilio ${ }^{1}$

1.Faculdade IPEMED de Ciências Médicas, São Paulo (SP), Brazil.

*Corresponding author: luiz234@hotmail.com

\section{BACKGROUND}

Leprosy is a chronic, infectious, contagious, granulomatous disease, caused by Mycobacterium leprae, which infects Schwann cells in peripheral nervous system. The disease mainly affects the superficial skin nerves and peripheral nerve trunks but can affect the eyes and internal organs. The evolution occurs, in general, slowly and progressively, and can lead to physical disabilities. The main manifestations of leprosy are: hypochromic spots, brownish or reddish, with alteration of sensitivity; tingling, shocks and cramps in the arms and legs, which evolve into numbness; hypotonia and reduction of the muscles innervated by these nerves; fever, arthralgia, edema of hands and feet with cyanosis and dry skin; chronic red eye, dryness and feeling of sand in the eyes, visual haze; arthralgias, arthritis, cramps, nodules on the joints and bone lesions of the hands and feet. Rheumatological manifestations are seen in $3 / 4$ of the patients and are considered the third most frequent manifestation of the disease. The main rheumatic manifestations are: acute polyarthritis (with erythema nodosum), acute rheumatoid-like polyarthritis (without erythema nodosum), acute monoarthritis, acute oligoarthritis, edematous or "succulent" hand, cutaneous vasculitis, Charcot disease and septic arthritis/osteomyelitis.

\section{MATERIALS AND METHODS}

Rheumatological tests were carried out on leprosy patients treated at Hospital Geral da Mirueira (Padre Antônio Manuel Sanatorium), which had previously been the state reference for leprosy. The bibliographic research was based on the digital platforms of Scholar Google, PubMed and SciELO.

\section{DISCUSSION}

Differentiating between leprosy and RA and other rheumatological diseases is difficult, especially when polyarthritis is the initial manifestation, in non-endemic sites of the disease. In addition to the joint inflammation of the two diseases, joint deformities can mimic RA, such as swan neck deformity, internal atrophy and ulnar deviation. Several autoantibodies can be detected in the serum of leprosy patients, including FR, FAN, antithyroglobulin, native anti-DNA, cryoglobulins and circulating immune complexes. The radiological changes are consequences of specific and unspecified injuries, which can cause periostitis, osteitis and osteomyelitis. The initial lesions include erosions and bone rarefaction. Osteoporosis can be diffuse, localized or periarticular and can be complicated by fractures.

\section{CONCLUSION}

Leprosy is a disease which clinical manifestations can simulate many rheumatic diseases. In addition, autoantibodies and even imaging tests may also present themselves in a similar manner, causing diagnostic doubt in the face of atypical presentations and when considering regions where the disease is not prevalent.

\section{REFERENCES}

1. Brazil. Ministério da Saúde. Secretaria de Vigilância em Saúde. Departamento de Vigilância das Doenças Transmissíveis. Diretrizes para vigilância, atenção e eliminação da Hanseníase como problema de saúde pública: manual técnico-operacional [Internet]. Brasília: Ministério da Saúde; 2016 [cited 2020 Dec 29]. Available from: https://portalarquivos2.saude.gov.br/images/pdf/2016/ fevereiro/04/diretrizes-eliminacao-hanseniase-4fev16-web.pdf

2. Brazil. Ministério da Saúde. Secretaria de Vigilância em Saúde. Departamento de Vigilância das Doenças Transmissíveis. Guia prático sobre a hanseníase [Internet]. Brasília: Ministério da Saúde; 2017 [cited 2020 Dec 29]. Available from: http://bvsms.saude. gov.br/bvs/publicacoes/guia_pratico_hanseniase.pdf

3. Carvalho MA, Lanna C, Bertolo M, Ferreira G. Reumatologia: Diagnóstico e Tratamento. 5. ed. Rio de Janeiro: Guanabara Koogan; 2019. 